\title{
A Study on the Relationship between Depression and Eating Disorders among College Students of Northern Gyeonggi-do, Korea
}

\author{
Heeseon Jang, Hyunggon Kang \\ Department of Health administration \& Social welfare and Health informatics, CHA University, Pocheon, Korea
}

Objectives: This study was conducted to identify the relationship between depression and eating disorders among college students of northern Gyeonggi-do in Korea. Methods: This was a self-report study, targeting a total number of 481 college students. We used the eating attitudes test-26 (EAT-26) to identify participants with eating disorders, while the degree of depression was evaluated by a self-diagnostic test composed of 10 questions. Results: Among the participants, 18.9\% were found to have an eating disorder (91 out of 481 participants). The depression score for students with eating disorders was markedly higher (4.73 points) than that for students with normal eating habits ( 2.57 points). We noted a statistically significant association between eating disorder and depression. Specifically, when depression score increased by 1 point, the risk of eating disorder was 1.31 times higher. Additional factors that increased the risk of having eating disorders besides depression were eating late, weight loss, degree of stress, and satisfaction with one's appearance. Conclusions: In this study, we found that depression plays an important role in the development of eating disorders. Therefore, it is need to develop programs to promote right eating habits and prevent depression for college students.

Key words: Depression, Eating disorders, Weight loss, Stress, Physical appearance

\section{INTRODUCTION}

Eating is a necessary activity for sustaining human life, and a balanced eating behavior sustains the physical fitness of our body. Physical fitness is important for retaining mental and emotional stability. However, media portrayals affect our society's beauty standards, nurturing a bias towards thin body shapes. As a result, there is an increase in cases of improper diet and eating disorders such as anorexia and bulimia, caused by incorrectly acknowledging oneself as being overweight.

Stein et al. [1] mention depression, anxiety, and stress as negative factors leading to bulimia. Negative emotions and hunger are shown to be significantly higher prior to binge eating in bulimic individuals, and patients often blame emotion rather than hunger for this binge eating. In addition, one of the most prominent symptoms of depression and other mental illnesses is the loss of appetite. Such loss prompts improper food

Corresponding author: Hyunggon Kang

120 Haeryong-ro, Pocheon 11160, Korea

Tel: +82-31-850-8962, E-mail: hgkang@cha.ac.kr

Received: February 1, 2017 Revised: March 30, 2017 Accepted: April 12, 2017

No potential conflict of interest relevant to this article was reported. intake, which results in severe weight loss. Anorexia nervosa may develop in severe cases, and is a serious eating disorder with a series of symptoms wherein patients show resistance to eating.

This study focused on depression, one of the most influential factors causing eating disorders, because most of the individuals that have abnormal eating behaviors are shown to experience high levels of depression [2]. Several studies focusing on the relationship between depression and eating disorders report that patients presenting with anorexia nervosa or bulimia are usually depressed [3]. Herzog et al. [4] reported that patients with eating disorders usually have coexisting psychopathological symptoms. One study reported that $35-85 \%$ of anorexia nervosa patients and 15-36\% of bulimia patients have depression [2]. Therefore, eating disorder and depression are closely related.

College students are in a transitional stage from adolescence to adulthood. Bad eating habits and lifestyle formed at this period have been re-

How to cite this article:

Jang $\mathrm{H}$, Kang $\mathrm{H}$. A study on the relationship between depression and eating disorders among college students of Northern Gyeonggi-do, Korea. J Health Info Stat 2017;42(2):108-115. Doi: https://doi.org/10.210 32/jhis.2017.42.2.108

(c) It is identical to the Creative Commons Attribution Non-Commercial License (http://creativecommons.org/licenses/by-nc/4.0) whichpermit sunrestricted non-commercial use, distribution, and reproduction in any medium, provided the original work is properly cited.

(C) 2017 Journal of Health Informatics and Statistics 
ported to cause lifestyle diseases such as cardiovascular disease, cancer, and osteoporosis in middle age and old age [5]. A study conducted with male and female college students shows that $0.7 \%$ of the students have anorexia nervosa and $0.8 \%$ have bulimia [6]. Other studies focusing on female college students have shown an increased percentage of female students with eating disorders, ranging from $3.4-5.9 \%$ in one study [7], with a higher rate of $12.6 \%$ in another [8]. Eating disorders can negatively affect one's health, emotions, relationships, and the ability to function in important areas of life. They can also cause physical and psychological damage to individuals, and even threaten one's life. Therefore, it is very important to design treatment strategies for patients with eating disorders. Currently, college students in South Korea appear to be more prone to depression due to the global economic crisis that results in fewer job opportunities and increased job competition [9]. Consequently, students' depression negatively affects their eating habits.

Most studies regarding the association between the degree of depression and eating disorders have been conducted on women and patients with eating disorders, but not on college students. Therefore, confirming the relationship between the level of depression and eating disorder in college students will help develop alternative nourishing diet plans for students with eating disorders. It is noteworthy that the level of depression contributes to behavioral changes and has a significant effect on practicing and sustaining various health behaviors [10].

Therefore, this study aimed to reveal the relationship between the degree of depression and eating disorder in college students, and to provide basic information that can be used to help college students who suffer from eating disorders return to healthier eating habits and choose a healthy and happy life.

\section{MATERIALS AND METHODS}

\section{Research participants and data collection method}

A questionnaire survey was conducted among 502 college students in northern Gyeonggi-do. Questionnaires were distributed from April 27, 2016 to May 4, 2016, and 502 copies were returned. Convenience sampling and self-report methods were used for data collection.

Out of the 502 total returned copies, 481 copies were used in the analysis; 21 copies were excluded because participants did not respond to one or more scales of the EAT-26 self-test, the responses were insufficient, or if the general questions were left unattended.

\section{Research tools}

The questionnaire used for the survey consisted of 23 questions about participants' characteristics, 26 questions for identifying eating disorder [11,12], and 10 questions as a depression self-diagnosis test [13].

\section{Eating disorder measurement tools}

Eating disorder risk was assessed with the Korean standardized version of EAT-26 [11], shortened and revised by Garner et al. [12] from the Eating Attitude Test-40 (EAT-40) developed by Garner and Garfinkel (1979). This 26-item, 6-point scale tool consists of three subscales: The first (1 to 13) is about dietary control, the second (14 to 19) is about bulimia and food preoccupation, and the third (20 to 26) is about oral control [11]. Sum of scores may range from 0 to 78 points: 0 was assigned to "Never", "Rarely", and "Sometimes"; 1 point to "Often"; 2 points to "Usually"; and 3 points to "Always". Higher scores than the benchmark of 15 for male and 18 for female participants were interpreted to signify higher tendencies towards eating disorders such as anorexia nervosa and bulimia [12]. The Cronbach' alpha was 0.83 .

\section{Depression measurement tools}

We created a 10-question self-diagnostic test including the 9 diagnostic standards of Major Depressive Disorder of DSM-IV (American Psychiatric Association) [13]. Students were asked to reply "Yes" to each question if they experienced each condition in question for longer than 2 weeks. This test has 10 questions for a binary decision. For a DSM-IV depression diagnosis, participants should have more than 5 out of the 9 specific symptoms including depressed mood, or decreased interest or pleasure in most activities [13]. In this study, participants who gave the answer "Yes" to 5 or more out of 10 questions were considered to suffer from high level of depression.

\section{Confounding variables}

In this study, self-satisfaction, degree of stress, and satisfaction with one's appearance were considered as confounding variables. Participants had to answer the following questions: "How satisfied are you with yourself?", "What is your stress level for the last two weeks?" and "How satisfied are you with your appearance?" to address those 3 variables. The answers they had to choose from were divided into three levels: high, normal, or low. 


\section{Data analysis}

Descriptive statistics were calculated to find the participants' general characteristics and eating disorders. Chi-square test was conducted to analyze differences in eating disorders according to the calculated descriptive statistics. Lastly, multiple logistic regression analysis was conducted in order to investigate the relationship between depression and eating disorder after controlling the confounding variables (general, mental, physical, and social characteristics). Statistical analyses were conducted using Minitab Statistical Software (Minitab version 17, Minitab Inc., USA).

\section{RESULTS}

\section{The characteristics of the research respondents}

Participants in this study were 481 college students $[70.5 \%(n=339)$ female and 29.5\% ( $\mathrm{n}=142)$ male] with average age $20.50( \pm 1.83)$ and a range between 18 and 29 years of age. Amongst the participants in this study, 34.9\% ( $\mathrm{n}=168)$ were sophomores, 29.5\% $(\mathrm{n}=142)$ were freshmen, $22.9 \%(n=110)$ were juniors, and $12.7 \%(n=61)$ were seniors. In this study, 49.1\% ( $\mathrm{n}=236)$ of students were majoring in health sciences, $21.2 \%$ $(n=102)$ in life sciences, $16.4 \%(n=79)$ in integrated social sciences, $11.6 \%$ ( $\mathrm{n}=56)$ in nursing, and $1.7 \%(\mathrm{n}=8)$ in Pharmacy.

Among the participants, $18.9 \%$ that belonged to the high risk group consisted of males who scored higher than 15 points and females who scored higher than 18 points and were found to have eating disorders, The average score of all the respondents was lower (10.26 \pm 8.60$)$. Responses with high scores included "I am afraid of gaining weight", "I cannot shake off the desire to be more slender", "I cannot shake off the thought that I am overweight".

Among the participants, $72.8 \%$ showed normal degree of depression (0-4 points), and $27.2 \%$ showed high degree of depression ( $\geq 5$ points). The following 3 factors scored higher among students: "tired or does not have enough energy", "difficult to concentrate and cannot decide", "cannot sleep and often have disturbed sleep or sleep too long" (Table 1).

\section{The Relationship between eating disorders and confounding variables}

Of the 91 college students with eating disorder, $42.9 \%$ exercised regularly, while the respective percentage for college students with normal eating behavior was much lower $(30.3 \%, p<0.05)$. Additionally, $49.5 \%$ students with eating disorders were eating late while the respective per-
Table 1. The characteristics of the research respondents

\begin{tabular}{|c|c|c|c|}
\hline \multirow{2}{*}{ Categories } & Male & Female & Total \\
\hline & $\mathrm{n}(\%)$ & n (\%) & $\mathrm{n}(\%)$ \\
\hline \multicolumn{4}{|l|}{ Grade } \\
\hline Freshman (1) & $52(10.8)$ & $90(18.7)$ & $142(29.5)$ \\
\hline Sophomore (2) & $43(8.9)$ & $125(26.0)$ & $168(34.9)$ \\
\hline Junior (3) & $35(7.3)$ & $75(15.6)$ & $110(22.9)$ \\
\hline Senior (4) & $12(2.5)$ & $49(10.2)$ & $61(12.7)$ \\
\hline \multicolumn{4}{|l|}{ Students'major } \\
\hline Nursing & $9(1.9)$ & $47(9.8)$ & $56(11.6)$ \\
\hline Health sciences & $77(16.0)$ & $159(33.1)$ & $236(49.1)$ \\
\hline Life sciences & $45(9.4)$ & $57(11.9)$ & $102(21.2)$ \\
\hline Pharmacy & $3(0.6)$ & $5(1.0)$ & $8(1.7)$ \\
\hline Integrated social sciences & $8(1.7)$ & $71(14.8)$ & 79 (16.4) \\
\hline \multicolumn{4}{|l|}{ Eating disorder } \\
\hline Yes & $20(4.2)$ & $71(14.8)$ & $91(18.9)$ \\
\hline No & $122(25.4)$ & $268(55.7)$ & $390(81.1)$ \\
\hline \multicolumn{4}{|l|}{ Depression } \\
\hline Yes & $23(4.8)$ & $108(22.5)$ & $131(27.2)$ \\
\hline No & $119(24.7)$ & $231(48.0)$ & $350(72.8)$ \\
\hline Total & $142(29.5)$ & $339(70.5)$ & $481(100.0)$ \\
\hline
\end{tabular}

centage of students with normal eating behaviors was higher (66.9\%). The proportion of college students with eating disorder who had weight loss was $60.4 \%$, which was much higher than the proportion of college students with normal eating behavior (22.6\%). In addition, 26.4\% of college students with eating disorder had experienced weight loss, which was significantly different from $33.3 \%$ of college students with normal eating behavior $(p<0.05)$. Furthermore, 58.2\% of college students with eating disorders had a higher degree of stress compared to students with normal eating behavior $(35.6 \%, p<0.05)$. Moreover, 33.3\% of college students with eating disorders had lower self-satisfaction than students with normal eating behavior $(13.6 \%, p<0.05)$. In addition, $31.9 \%$ of college students with eating disorders had low satisfaction with one's appearance, compared to students with normal eating behavior (18.5\%, $p<0.05)$. In the case of students working part-time, $39.6 \%$ of college students suffered from an eating disorder, which is significantly different from $24.4 \%$ of college students with normal eating behavior $(p<0.05)$. However, sex, age, grade, residence, monetary allowance, body mass index, smoking, drinking, regular eating habit, fast-food intake frequency, dating, SNS (social networking systems) utilization frequency, and family intimacy was not different between students with or without eating disorders $(p>0.05)$ (Table 2). 
Table 2. The relationships between eating disorder and confounding variables

\begin{tabular}{|c|c|c|c|c|c|}
\hline \multirow{3}{*}{ Variables } & \multirow{3}{*}{ Group } & \multicolumn{3}{|c|}{ Eating disorder } & \multirow{3}{*}{$p$-value } \\
\hline & & \multirow{2}{*}{$\begin{array}{c}\text { Yes } \\
\mathrm{n}(\%)\end{array}$} & \multirow{2}{*}{$\begin{array}{c}\text { No } \\
\mathrm{n}(\%)\end{array}$} & \multirow{2}{*}{$\begin{array}{l}\text { Total } \\
\mathrm{n}(\%)\end{array}$} & \\
\hline & & & & & \\
\hline \multirow[t]{2}{*}{ Sex } & Male & $20(22.0)$ & $122(31.3)$ & $142(29.5)$ & 0.080 \\
\hline & Female & $71(78.0)$ & $268(68.7)$ & $339(70.5)$ & \\
\hline \multirow[t]{3}{*}{ Age (y) } & Teenager & $29(31.9)$ & $119(30.5)$ & $148(30.8)$ & 0.833 \\
\hline & $20-23$ & $56(61.5)$ & $238(61.0)$ & $294(61.1)$ & \\
\hline & $\geq 24$ & $6(6.6)$ & $33(8.5)$ & $39(8.1)$ & \\
\hline \multirow[t]{4}{*}{ Grade } & Freshman (1) & $25(27.5)$ & $117(30.0)$ & $142(29.5)$ & 0.361 \\
\hline & Sophomore (2) & $33(36.3)$ & $135(34.6)$ & $168(34.9)$ & \\
\hline & Junior (3) & $17(18.7)$ & $93(23.8)$ & $110(22.9)$ & \\
\hline & Senior (4) & $16(17.6)$ & $45(11.5)$ & $61(12.7)$ & \\
\hline \multirow[t]{2}{*}{ Residence } & Living with family & $46(50.5)$ & $173(44.4)$ & $219(45.5)$ & 0.286 \\
\hline & Living away from family & 45 (49.5) & $217(55.6)$ & $262(54.5)$ & \\
\hline \multirow[t]{4}{*}{ Allowance (10,000 won/mon) } & $<20$ & $19(20.9)$ & $76(19.5)$ & 95 (19.8) & 0.598 \\
\hline & $20-29$ & $22(24.2)$ & $108(27.7)$ & $130(27.0)$ & \\
\hline & $30-39$ & $38(41.8)$ & $139(35.6)$ & $177(36.8)$ & \\
\hline & $\geq 40$ & $12(13.2)$ & $67(17.2)$ & $79(16.4)$ & \\
\hline \multirow[t]{4}{*}{ BMI } & Underweight & $10(12.2)$ & $66(18.6)$ & $76(17.4)$ & 0.369 \\
\hline & Normality & $55(67.1)$ & $217(61.1)$ & $272(62.2)$ & \\
\hline & Overweight & $13(15.9)$ & $45(12.7)$ & $58(13.3)$ & \\
\hline & Obesity & $4(4.8)$ & $27(7.6)$ & $31(7.1)$ & \\
\hline \multirow[t]{3}{*}{ Smoking } & Yes & $10(11.0)$ & $33(8.5)$ & $43(8.9)$ & 0.116 \\
\hline & No & $74(81.3)$ & $344(88.2)$ & $418(86.9)$ & \\
\hline & Experience & $7(7.7)$ & $13(3.3)$ & $20(4.2)$ & \\
\hline \multirow[t]{4}{*}{ Drinking (times a wk) } & $<1$ & 44 (48.4) & $156(40.0)$ & $200(41.6)$ & 0.518 \\
\hline & $1-2$ & $21(23.1)$ & $110(28.2)$ & $131(27.2)$ & \\
\hline & $\geq 3$ & $5(5.5)$ & $27(6.9)$ & $32(6.7)$ & \\
\hline & No & $21(23.1)$ & $97(24.9)$ & $118(24.5)$ & \\
\hline \multirow[t]{2}{*}{ Regular exercise } & Yes & $39(42.9)$ & $118(30.3)$ & $157(32.6)$ & 0.021 \\
\hline & No & $52(57.1)$ & $272(69.7)$ & $324(67.4)$ & \\
\hline \multirow[t]{2}{*}{ Regular eating habits } & Yes & $46(50.5)$ & $232(59.5)$ & $278(57.8)$ & 0.120 \\
\hline & No & 45 (49.5) & $158(40.5)$ & $203(42.2)$ & \\
\hline Eating late & Yes & $45(49.5)$ & $261(66.9)$ & $306(63.6)$ & 0.002 \\
\hline & No & $46(50.5)$ & $129(33.1)$ & $175(36.4)$ & \\
\hline Frequency of eating fast food & $<4 /$ wk & $56(61.5)$ & $258(66.2)$ & $314(65.3)$ & 0.405 \\
\hline & $\geq 4 / w k$ & $35(38.5)$ & $132(33.8)$ & $167(34.7)$ & \\
\hline Weight loss & Yes & $55(60.4)$ & $88(22.6)$ & $143(29.7)$ & $<0.001$ \\
\hline & No & $12(13.2)$ & $172(44.1)$ & $184(38.3)$ & \\
\hline & Experience & $24(26.4)$ & $130(33.3)$ & $154(32.0)$ & \\
\hline Degree of stress & High & $53(58.2)$ & $139(35.6)$ & $192(39.9)$ & $<0.001$ \\
\hline & Normal & $25(27.5)$ & $198(50.8)$ & $223(46.4)$ & \\
\hline & Low & $13(14.3)$ & $53(13.6)$ & $66(13.7)$ & \\
\hline Self-satisfaction & High & $36(39.6)$ & $196(50.3)$ & $232(48.2)$ & $<0.001$ \\
\hline & Normal & $25(27.5)$ & $141(36.2)$ & $166(34.5)$ & \\
\hline & Low & $30(33.0)$ & $53(13.6)$ & $83(17.3)$ & \\
\hline Satisfaction with one's appearance & High & $37(40.7)$ & $134(34.4)$ & $171(35.6)$ & $<0.001$ \\
\hline & Normal & $25(27.5)$ & $184(47.2)$ & $209(43.5)$ & \\
\hline & Low & 29 (31.9) & $72(18.5)$ & $101(21.0)$ & \\
\hline Part-time job & Yes & $36(39.6)$ & $95(24.4)$ & $131(27.2)$ & 0.003 \\
\hline & No & $55(60.4)$ & 295 (75.6) & $350(72.8)$ & \\
\hline Dating & Yes & $31(34.1)$ & $113(29.0)$ & 144 (29.9) & 0.340 \\
\hline & No & $60(65.9)$ & $277(71.0)$ & $337(70.1)$ & \\
\hline Use of SNS & Yes & $53(58.2)$ & 209 (53.6) & $262(54.5)$ & 0.588 \\
\hline & Normal & $22(24.2)$ & $94(24.1)$ & $116(24.1)$ & \\
\hline & None & $16(17.6)$ & $87(22.3)$ & $103(21.4)$ & \\
\hline Family intimacy & Intimate & 65 (71.4) & $312(80.0)$ & $377(78.4)$ & 0.084 \\
\hline & Normal & $21(23.1)$ & 70 (17.9) & 91 (18.9) & \\
\hline & Non-intimate & $5(5.5)$ & $8(2.1)$ & $13(2.7)$ & \\
\hline
\end{tabular}

Body mass index (BMI) was calculated by dividing a person's weight in kilogram by square of a person's height in meters. Depending on the index, a person was categorized as underweight $(\mathrm{BMl}<20)$, normality $(20 \leq \mathrm{BMl}<25)$, overweight $(25 \leq \mathrm{BMl}<30)$, and obesity $(\mathrm{BMI} \geq 30)$. 
Table 3. The relationships between eating disorders and depression

\begin{tabular}{|c|c|c|c|c|c|}
\hline \multirow{3}{*}{ Variables } & \multirow{3}{*}{ Group } & \multicolumn{3}{|c|}{ Eating disorder } & \multirow{3}{*}{$p$-value } \\
\hline & & Male & Female & Total & \\
\hline & & n (\%) & n (\%) & n (\%) & \\
\hline \multirow[t]{2}{*}{ Depression } & Yes & $48(52.7)$ & $83(21.3)$ & $131(27.2)$ & $<0.001$ \\
\hline & No & 43 (47.3) & 307 (78.7) & $350(72.8)$ & \\
\hline
\end{tabular}

\section{The relationship between eating disorders and depression}

According to the results of our study, 52.7\% of the college students who had eating disorders and $21.3 \%$ students with normal eating behavior showed high degree of depression. This difference shows that depression is often associated with an eating disorder $(p<0.05)$ (Table 3).

\section{Multiple logistic regression analysis of variables showing significant differences}

Multiple logistic regression analysis revealed that depression level, eating late, weight loss, degree of stress, and satisfaction with one's appearance showed statistically significant differences despite the control of other exogenous variables $(p<0.05)$. When depression scores increased by 1 point, the eating disorder risk increased 1.31 times, showing a statistically significant association $(p<0.05)$. Students who have been eating late showed a 0.55 times higher risk of eating disorders than those who have no eating late, showing a statistically significant difference $(p<0.05)$. Participants that were actively losing weight showed a 7.25 times higher risk of developing an eating disorder compared to those that had no desire to lose weight, showing a statistically significant difference $(p<0.05)$. In addition, students who had experienced weight loss showed a 2.44 times higher risk of eating disorders than those who had no weight loss experience, showing a statistically significant difference $(p<0.05)$. Students who presented with a high degree of stress showed a 3.06 times higher risk of eating disorders than those with lower degree of stress, showing statistically a significant difference $(p<0.05)$. Finally, students who had higher satisfaction with their appearance showed 3.71 times the risk of eating disorder than those with lesser satisfaction with their appearance, showing statistically significant difference $(p<0.05)$.

Other variables, including regular exercise, self-satisfaction, and parttime job showed a difference between the groups, but it was not statistically significant $(p>0.05)$ (Table 4$)$.
Table 4. Impact of each variable on eating disorder through multiple logistic regression analysis

\begin{tabular}{lc}
\hline Variables & OR $(95 \% \mathrm{Cl})$ \\
\hline Depression (score) & $1.31(1.15-1.48)$ \\
Regular exercise, yes & $1.14(0.62-2.09)$ \\
Eating late, yes & $0.55(0.32-0.95)$ \\
Weight loss (ref. no) & \\
$\quad$ Yes & $7.25(3.35-15.68)$ \\
$\quad$ Experience & $2.44(1.11-5.38)$ \\
Stress (ref. low) & \\
$\quad$ High & $3.06(1.04-8.99)$ \\
$\quad$ Normal & $0.99(0.52-1.87)$ \\
Self-satisfaction (ref. low) & \\
$\quad$ High & $0.47(0.13-1.73)$ \\
$\quad$ Normal & $0.67(0.32-1.44)$ \\
Satisfaction with one's appearance (ref. low) & \\
$\quad$ High & $3.71(1.02-13.53)$ \\
$\quad$ Normal & $1.68(0.79-3.56)$ \\
Part-time jobs, yes & $1.60(0.91-2.82)$ \\
\hline
\end{tabular}

$\mathrm{OR}$, odds ratio; $\mathrm{Cl}$, confidence interval.

\section{DISCUSSION}

College students in their late adolescence are in a unique period of transition between youth and adulthood, where they have to adapt to the society in an environment that they have never experienced before, and they have greater responsibilities for social advancement such as studying and employment. Facing these challenges, many college students are prone to depression.

Korean college students often suffer from serious depression. College students are more prone to depression than middle and high school students, and they are found to suffer from severe emotional maladjustment [14]. Adults in their 20-30s are at crossroads and make efforts to achieve their goals. However, frustration about reality and inability to achieve their goals often leads to depression and loss of self-confidence.

This study was designed to identify the degree of eating disorders among college students and to examine the influence of depression on eating disorders. While there are various reasons for binge eating-a major symptom of eating disorders-this study was conducted on the basis of the findings of previous studies indicating depression as a main cause of binge eating behavior.

We found statistically significant correlation when we analyzed the risk of eating disorder according to the degree of depression. For every one point of increase in depression score, the eating disorder risk in- 
creases 1.31 times. This result shows that the higher the depression degree, the higher risk of getting an eating disorder. These results agree with Berg et al. [15] and Macabe [16], which show that depression has a significant influence on eating disorders.

Depression is caused by the interaction between the various psychological, physical, and social factors [17]. No psychobiological mechanism that relates depression and eating behaviors has been clarified so far, but Schore [18] reported that the inability to regulate emotions in developmental processes enhances psychological instability and pathological symptoms in major psychological conditions. This suggests that eating disorders are unconscious emotional control disorders caused by excessive depression or negative emotions. During this process, food becomes a factor controlling the negative emotions that threaten the individuals.

These results suggest that the eating behavior of college students is very closely related to the degree of depression. Therefore, we think that it is necessary to seek a continuous and systematic method to manage and reduce college students' depression and minimize the chances of reoccurrence.

Multiple logistic regression analysis to elucidate the degree of relationship between depression and eating disorders after adjusting for confounding variables like eating late, weight loss, weight loss experience, stress, and physical appearance showed significant results. However, regular exercise, self-satisfaction, and part time job were not related to eating disorder risk.

First, eating late showed a significant association in the relationship with eating disorders. However, the students who have been eating late showed 0.55 times higher risk of eating disorder. These results are contradictory to the anticipated results that pre-existing undesirable eating habits tend to easily cause eating disorder [19]. It is possible that eating late could relate to a fear of gaining weight and this could have affected the results of the study. Second, a desire to lose weight and weight loss experience showed significant differences in relationship with eating disorders. Students with a desire for weight loss showed 7.25 times higher risk of eating disorder than students without a desire for weight loss. Additionally, students who had experienced weight loss showed 2.44 times higher risk of eating disorder than students who had not experienced weight loss. This is consistent with the findings of Paek et al. [20], which reported that weight control is a variable with the greatest explanatory power and affects eating disorders. Efforts to address pressures on body image as well as the processing of food-related stimuli affect eating dis- orders [21]. Consequently, unreasonable weight loss could affect eating disorders, and weight loss actually has significant correlations with eating disorders. Third, student groups that were presented with high stress showed higher eating disorder risk than low stress groups. Statistical analyses showed that when one experiences severe stress, the risk of eating disorder is 3.06 times higher. These results are consistent with the findings of Ahn [22] that suggest that eating disorder level increases with the stress level. Fourth, students that get lower satisfaction with physical appearance have also a lower risk for an eating disorder. This result is in contrast to the current notion that negative perception of oneself is the cause of eating disorder [23]. However, due to the influence of the importance given to appearance, the students who are satisfied with their appearance struggle to maintain it, which may render them prone to abnormal eating behaviors. Additional research should be performed using tools that can use continuous scores to identify additional variables clarifying the relevance in detail between the satisfaction with the appearance and eating disorder.

This study had several limitations. First, convenient sampling and the restricted survey area limit the reliability of the participants' responses. Thus, caution should be used in the generalization of the findings. Second, this study used a questionnaire as the only research tool. Third, the questionnaire survey was a cross-sectional study, and any temporal relationship is not clear.

Despite these limitations, this study has significant connotations, because it identifies depression as a factor that affects the risk of eating disorders among college students, and corroborates previous studies that show that depression causes eating disorders. These results make us ponder where to focus on in order to help students who suffer from eating disorders. Our questionnaire may be modified to include students at risk of eating disorder, even if they are not diagnosed with an eating disorder yet. The results of this study can help design strategies to prevent depression and formulate healthy eating habits for college students.

\section{CONCLUSIONS AND RECOMMENDATIONS}

In essence, this study suggests that depression plays an important role in the development of eating disorders. If eating disorders are not treated properly, they may become very serious. Therefore, it is important to find methods to promote right eating habits and reduce depression for college students. 
In addition, it is required to offer psychological support to vulnerable groups of students and offer treatment plans for the affected ones, helping them choose a healthy and happy life.

\section{REFERENCES}

1. Stein RI, Kenardy J, Wiseman CV, Dounchis JZ, Arnow BA, Wilfley DE. What's driving the binge in binge eating disorder?: a prospective examination of precursors and consequences. Int J Eat Disord 2007;40 (3);195-203.

2. Wolff GE, Crosby RD, Roberts JA, Wittrock DA. Differences in daily stress, mood, coping, and eating behavior in binge eating and nonbinge eating college women. Addict Behav Rep 2000;25(2);205-216.

3. Park JE, Kim SJ, Choue RW. Study on stress, depression, binge eating, and food behavior of high school girls based on their BMI. Nutr Res Pract 2009;14(2);175-181 (Korean).

4. Herzog DB, Keller MB, Lavori PW, Ott IL. Short-term prospective study of recovery in bulimia nervosa. Psychiatry Res 1988;23(1);45-55.

5. Schlenker ED. Nutrition in aging. 3rd ed. Boston: MCGraw-Hill, 1998, p. 194-204.

6. Han OS, Yu HJ, Kim CY, Lee C, Min BG, Park IH. The epidemiology and personality characteristics of eating disorders in Korea. Seoul J Psychiatry 1990;15(0);270-287 (Korean).

7. Song GA, Park JS. Eating habits, trend of disordered eating, weight reduction practice and body size evaluation of college students in Seoul. Korean J Women Health Nurs 2003;9(4);457-466 (Korean).

8. Choi MS, Cheon SH. Internalization of the sociocultural attitudes, body shape satisfaction, anger and eating attitudes in college women. Korean J Women Health Nurs 2007;13(4);327-335 (Korean).

9. Kim KS, Kim JN, Park WM, Cheon SM. The analysis of the component concepts on college students; psychological well-being. J Humanities 2006;11(1);1-23 (Korean).

10. Schlicht W. Does physical exercise reduce anxious emotions? A metaanalysis. Anxiety Stress Coping 1994;6(4);275-288.

11. Lee MK, Lee YH, Park SH, Son CH, Jung YJ, Hong SK, et al. A standardization study of the Korean version of eating attitudes Test-26 I: reliability and factor analysis. Korean Psychosom Soc 1998;6(2):155-
175 (Korean).

12. Garner DM, Olmsted MP, Bohr Y, Garfinkel PE. The eating attitudes test: psychometric features and clinical correlates. Psychol Med 1982; 12(4):871-879.

13. American Psychiatric Association. DSM-IV: diagnostic and statistical manual. Washington (DC): American Psychiatric Association; 1994.

14. Kang SK, Ko SH, Han SH. The mediating effect of internalized shame in the relationships among students social anxiety, negative emotion, covert narcissism and depression. CNU J Educ Stud 2011;32(2):1-27 (Korean).

15. Berg A, Allan JD, Frame PS, Homer CJ, Johnson MS, Klein JD, et al. Screening for depression. Ann Intern Med 2002;136(10):760-764.

16. McCabe MP, Vincent MA. The role of biodevelopmental and psychological factors in disordered eating among adolescent males and females. Eur Eat Disord Rev 2003;11(4):315-328.

17. VanBoven AM, Espelage DL. Depressive symptoms, coping strategies, and disordered eating among college women. J Couns Dev 2006;84(3): 341.

18. Schore JR, Schore AN Modern attachment theory: the central role of affect regulation in development and treatment. Clin Soc Work J 2008;36(1):9-20.

19. Kim SY. The relationship between obesity degree and psychological factors, dietary behaviors and health-related quality of life in adult women in their twenties in Seoul and Kyungin Area. Prev Nutr Food Sci 2013;26(3):535-546 (Korean).

20. Paek YJ, Kang HE, Leem KE, Leem SY, Hwang SJ, Yoo TW. EAT score according to weight control, depression level and body mass index (BMI). Korean J Fam Med 2001;22(5):690-697 (Korean).

21. Finlayson G, King N, Blundell JE. Liking vs. wanting food: importance for human appetite control and weight regulation. Neuro Sci Bio Behav Rev 2007;31(7):987-1002.

22. Ahn GYR. The effect of stress experiences on abnormal eating behavior of female high school students. Korean J Str Res 2011;19(3):213220. (Korean).

23. Lee GH, Kim SK, Chun KJ, Han SH. The relationship between eating disorder and self-esteem in female college students. Korean J Women Health Nurs 2003;9(4):390-399 (Korean). 


\section{국문초록}

목적: 이 연구는 경기 북부 대학생을 대상으로 우울 정도와 이상섭식과의 관계를 규명하고자 수행되었다.

방법: 이 연구는 경기북부 대학생 총 481 명을 대상으로 자기기입방식의 설문조사를 실시하였다. 이상 섭식 유무를 파악하기 위해서 Garner와 Garfinkel (1979)이 개발한 Eating Attitude Test-40 (EAT-40)을 우리나라에서 표준화한 섭식 태도 검사(Eating Attitude Test-26, EAT-26)를 활용하였고, 우울 정도를 파악하기 위해 DSM-IV (미국정신협회)의 우울증 진단 기준에 따른 10 문항의 자가 우울증 진단 테 스트를 연구 도구로 사용하였다.

결과: 이상섭식태도를 보이는 대학생은 91 명으로 전체 연구대상의 $18.9 \%$ 이었다. 이상 섭식 태도를 보이는 대학생의 경우 우울 정도의 평균은 4.73점으로 정상적인 섭식 태도를 보이는 대학생의 우울 정도의 평균 2.57점보다 높았다. 이상 섭식과 우울 정도 간에는 통계적 으로 유의한 차이를 보였으며, 우울 점수가 1점 증가할 때 이상 섭식 발생 위험이 1.31 배임을 볼 수 있었다. 우울 정도 이외에 이상 섭식에 영향을 미치는 요인은 야식, 체중감량여부, 스트레스, 외모 만족도였다.

결론: 이 연구를 통해 우리는 이상 섭식에 우울 정도가 중요한 역할을 한다는 것을 확인할 수 있었다. 따라서, 대학생의 올바른 섭식 태 도 증진과 우울증 예방을 위한 프로그램의 개발이 필요하다고 사료된다.

주제어: 우울증, 이상 섭식, 체중감량, 스트레스, 외모 만족도 